\title{
An Atlas of Lumps and Bumps: Part 13
}

\author{
Alexander K. C. Leung, MD ${ }^{1,2}$-Series Editor - Benjamin Barankin, $\mathrm{MD}^{3}$ - Joseph M. Lam, MD4 - Kin Fon Leong, MD
}

\section{Ranula}

A ranula is a large mucus-containing, cyst-like mass caused by extravasation and accumulation of mucus from a major salivary gland (most commonly the sublingual salivary gland) into the surrounding tissue in the floor of the mouth. ${ }^{1-4}$ The condition can be congenital or iatrogenic. ${ }^{2,5}$ Congenital ranulas may result from an imperforate salivary duct or ostial adhesion. ${ }^{4}$ latrogenic ranulas may result from trauma to or obstruction of an excretory duct of a major salivary gland. ${ }^{2,6}$ Because ranulas are lined with granulation tissue instead of epithelium, they are considered a type of pseudocyst.,4

The prevalence rate of ranulas is 2 cases per 10,000 persons. ${ }^{3,5,6}$ Individuals in their second and third decades of life are more commonly affected. ${ }^{2,4,7}$ The sex ratio is approximately equal. ${ }^{2,6}$ There is no racial predilection. ${ }^{6}$

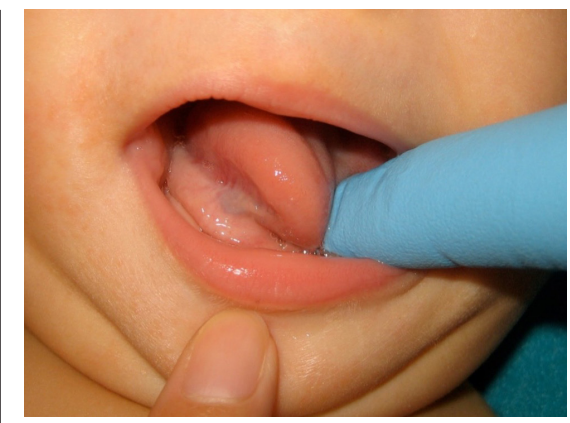

\section{Figure 1.}

Typically, a simple (or intraoral) ranula presents as a slow-growing, thin-walled, translucent to bluish, fluctuant, painless, round or oval swelling in the floor of the mouth that resembles the belly of a frog (Figures 1 and 2). ${ }^{3,5,6}$ In fact, the term "ranula" is derived from the Latin word "rana," meaning belly of the frog. ${ }^{4}$ Large lesions might lead to speech impairment, difficulty with mastication, dysphagia, and rarely, airway blockage and obstructive

\section{AFFILIATIONS:}

'Department of Pediatrics, University of Calgary, Calgary, Alberta, Canada

${ }^{2}$ Alberta Children's Hospital, Calgary, Alberta, Canada

${ }^{3}$ Toronto Dermatology Centre, Toronto, Ontario, Canada

${ }^{4}$ Department of Pediatrics and Department of Dermatology and Skin Sciences, University of British Columbia, Vancouver, British Columbia, Canada

${ }^{5}$ Pediatric Institute, Kuala Lumpur General Hospital, Kuala Lumpur, Malaysia

\section{CITATION:}

Leung AKC, Barankin B, Lam JM, Leong KF. An atlas of lumps and bumps, part 13. Consultant. 2022;62(2):e33-e35. doi:10.25270/con.2022.01.00005

\section{DISCLOSURES:}

Dr Leung is the series editor. He was not involved with the handling of this paper, which was sent out for independent external peer review.

\section{CORRESPONDENCE:}

Alexander K. C. Leung, MD, \#200, 233 16th Ave NW, Calgary, AB T2M 0H5, Canada (aleung@ucalgary.ca)

\section{EDITOR'S NOTE:}

This article is part of a series describing and differentiating dermatologic lumps and bumps. To access previously published articles in the series, visit https://www.consultant360.com/resource-center/atlaslumps-and-bumps.

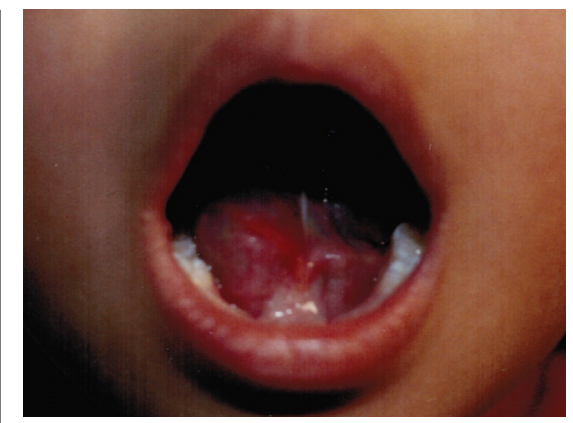

Figure 2.

sleep apnea. ${ }^{2,3}$

A plunging (or cervical) ranula occurs when a portion of the sublingual gland herniates through a dehiscence in the mylohyoid muscle with its extravasated mucin into the submandibular and submental space. ${ }^{1,78}$ Typically, a plunging ranula presents as an asymptomatic, fluctuant to soft cervical mass without swelling of the floor of the mouth. The swelling is usually unilateral but may cross the midline. ${ }^{6} \mathrm{~A}$ mixed ranula, on the other hand, presents with both intraoral and cervical swelling.

\section{Mucocele}

Mucoceles are the most common mucus cyst occurring in the oral cavity., The incidence in the general population is estimated to be $0.2 . \% .{ }^{6} \mathrm{~A}$ mucocele is caused by a traumatic severed or blocked duct of a minor salivary gland., ${ }^{6,1,12} \mathrm{~A}$ traumatic severed duct of a minor salivary gland is most often caused by lip biting during chewing, habitual lip biting, or accidental injury to the lip. 6,9,13 This leads to extravasation and accumulation of mucin in submucous tissue, referred to as an extravasation mucocele. ${ }^{10}$ The extravasated mucin is surrounded by condensed connective tissue with a 


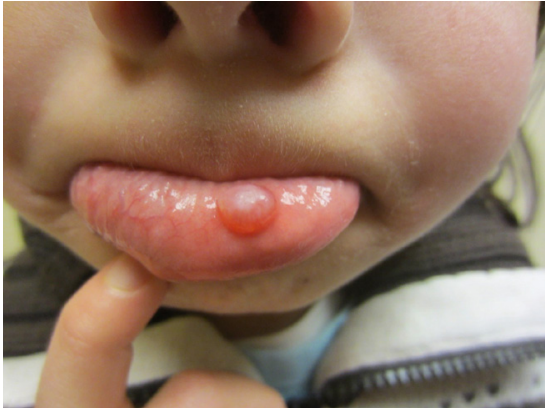

Figure 3.

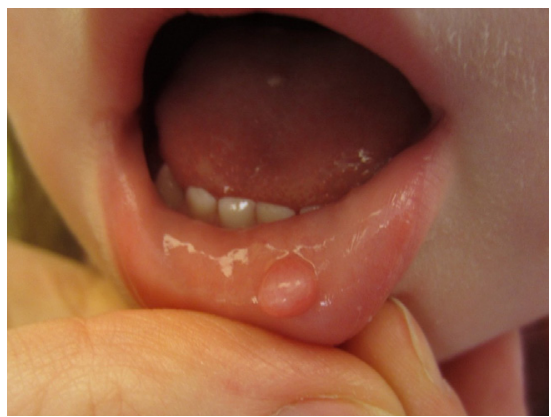

Figure 4.

variable amount of inflammation. ${ }^{10,14}$ No epithelial lining is present. ${ }^{15}$ The lower lip is the most frequent site of the extravasation cyst because it is the area most often susceptible to trauma. ${ }^{13,16}$ A retention mucocele, on the other hand, results from obstruction of the duct of a minor salivary gland.10,17 The obstruction may be caused by epithelial proliferation, trauma, or a sialolith. ${ }^{18,19}$ The trapped mucus is lined by columnar or cuboidal ductal epithelium. ${ }^{14}$ Approximately $90 \%$ of mucoceles are extravasation mucoceles and the remaining $10 \%$ retention mucoceles. ${ }^{20}$

Mucoceles affect patients of all ages with peak incidence in the first and second decades of life. ${ }^{10,20}$ Both sexes are equally affected. ${ }^{15,17,20}$ There is no racial predilection. ${ }^{19}$

Typically, a mucocele, irrespective of its etiology, presents as an asymptomatic, fluctuant, tense, well-circumscribed, dome-shaped swelling or nodule on the mucosal surface of the lip (Figures 3 and 4) ${ }^{10,16,21}$ More than $70 \%$ of cases occur on the lower lip. ${ }^{22}$ Less commonly, the mucocele occurs on the upper lip and buccal mucosa. The size of the lesion ranges

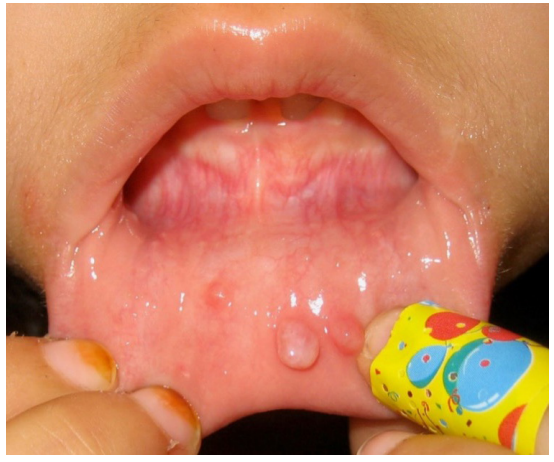

Figure 5.

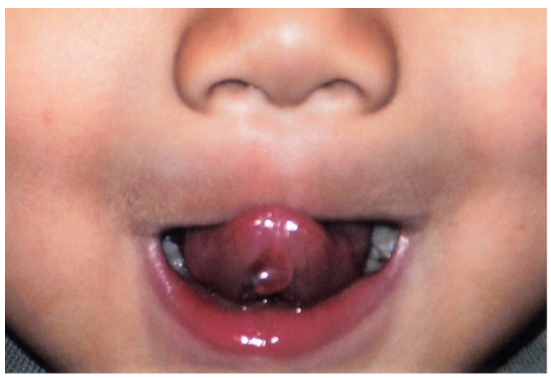

Figure 6

from a few millimeters to a few centimeters in diameter. ${ }^{18}$ The color ranges from deep blue to pink (the color of normal mucosa). ${ }^{15,20,21}$ A mucocele may fluctuate in size and rupture spontaneously. ${ }^{19}$ Lesions are usually solitary but can be multiple (Figure 5). ${ }^{23}$

Occasionally, mucoceles may occur on the floor of the mouth, soft palate, hard palate, and tongue. ${ }^{12,20,22,24}$ The occurrence on the tongue accounts for approximately $2 \%$ of cases. ${ }^{25}$ Rarely, a mucocele may arise on the ventral surface of the tongue and is known as mucocele of the gland of Blandin-Nuhn.14,26 The glands of Blandin-Nuhn are located in the anterior ventral surface of the tongue. $14,16,20,27$ These glands are arranged in a mass with a horseshoe shape and covered by thin mucous membrane.$^{14,16}$ In most cases, a mucocele of the gland of Blandin-Nuhn results from a self-inflicted bite wound. ${ }^{16,27}$ The lesion is usually less than $1 \mathrm{~cm}$ in diameter. Rapid onset, fluctuation in size, bluish discoloration and fluid-filled consistency are characteristic. ${ }^{25} \mathrm{~A}$ superficial mucocele, a rare subtype of the mucocele of the gland of Blandin-Nuhn, may pres- ent as a translucent fluid-filled vesicle or cyst (Figure 6). ${ }^{28,29}$ The lesion ruptures easily and may leave a slightly painful erosion, which usually heals within a few days.

The diagnosis of oral mucoceles is mainly clinical. Depending on the size and location, a mucocele can become cosmetically unsightly. ${ }^{9} \mathrm{~A}$ mucocele may persist for weeks or months before it ruptures spontaneously. Recurrence is common and may lead to fibrosis. ${ }^{10}$

\section{References}

1. Choi MG. Case report of the management of the ranula. J Korean Assoc Oral Maxillofac Surg. 2019;45(6):357-363. https://doi. org/10.5125/jkaoms.2019.45.6.357

2. Hassan BM, Intan Suhana MA, Megat Mustaqim MI. Bluish swelling on the floor of the mouth. Malays Fam Physician. 2020;15(1):64-67. https://e-mfp.org/ wp-content/uploads/2020/03/v15n1-testyour-knowledge-2.pdf

3. Sathanantham DK, Shah GB, Ulüalp $S$. Rapid development of a simple ranula in a child. Ann Otol Rhinol Laryngol. 2015;124(4):322-325. https://doi. org/10.1177/0003489414553653

4. Suresh BV, Vora SK. Huge plunging ranula J Maxillofac Oral Surg. 2012;11(4):487-490. https://doi.org/10.1007/s12663-010-0154-0

5. Mneimneh S, Barazi R, Rajab M. A rare case of congenital ranula in an infant. Case Rep Otolaryngol. 2016;2016:5874595. https://doi. org/10.1155/2016/5874595

6. Huzaifa M, Soni A. Mucocele and ranula. In: StatPearls. Treasure Island (FL): StatPearls Publishing; July 30, 2021. http://www.ncbi. nlm.nih.gov/books/nbk560855/

7. Liman ARUA, Tuang GJ, Mansor M Plunging ranula. Ear Nose Throat J. 2021;100(10_suppl):1004S-1005S. https:// doi.org/10.1177/0145561320927828

8. Yin T, Jain P, Ahmad Z, Morton RP. Patient with synchronous bilateral plunging ranulae. ANZ J Surg. 2019;89(11):E533-E535. https://doi.org/10.1111/ans.14865

9. Krol DM, Keels MA. Oral conditions. Pediatr Rev. 2007;28(1):15-22. https://doi. org/10.1542/pir.28-1-15

10. Leung AKC. Mucocele. In: Leung AKC, ed. 
Common Problems in Ambulatory Pediatrics: Specific Clinical Problems. 2nd ed. Nova Science Publishers, Inc.; 2011; 129-132.

11. Karthikeyan M, Varghese AK, Vasupradha G, Dinakaran J. Mucocele: a diagnostic dilemma!! J Pharm Bioallied Sci. 2016;8(Suppl 1):S168-S170. https://doi.org/10.4103/09757406.191951

12. Nallasivam KU, Sudha BR. Oral mucocele: review of literature and a case report. J Pharm Bioallied Sci. 2015;7(Suppl 2):S731-S733. https://doi.org/10.4103/09757406.163516

13. Chaitanya P, Praveen D, Reddy M. Mucocele on lower lip: a case series. Indian Dermatol Online J. 2017;8(3):205-207. https://doi. org/10.4103/idoj.idoj_151_16

14. Nico MM, Park JH, Lourenço SV. Mucocele in pediatric patients: analysis of 36 children. Pediatr Dermatol. 2008;25(3):308311. https://doi.org/10.1111/j.15251470.2008.00672.x

15. Granholm C, Olsson Bergland K, Walhjalt H, Magnusson B. Oral mucoceles; extravasation cysts and retention cysts. A study of 298 cases. Swed Dent J. 2009;33(3):125130. https://europepmc.org/article/ med/19994562

16. Baurmash HD. Mucoceles and ranulas. $J$ Oral Maxillofac Surg. 2003;61(3):369-378. https://doi.org/10.1053/joms.2003.50074

17. Huang IY, Chen $\mathrm{CM}, \mathrm{Kao} \mathrm{YH}$, Worthington P. Treatment of mucocele of the lower lip with carbon dioxide laser. J Oral Maxillofac Surg. 2007;65(5):855-858. https://doi. org/10.1016/j.joms.2006.11.013

18. Mustapha IZ, Boucree SA Jr. Mucocele of the upper lip: case report of an uncommon presentation and its differential diagnosis. J Can Dent Assoc. 2004;70(5):318-321. https://jcda.ca/sites/default/files/back_issues/vol-70/issue-5/318.pdf

19. Patel NJ, Sciubba J. Oral lesions in young children. Pediatr Clin North Am. 2003;50(2):469-486. https://doi.org/10.1016/ s0031-3955(03)00032-4

20. Titsinides S, Kalyvas D, Tosios K. Mucocele of the dorsal surface of the tongue: a case report. J Clin Exp Dent. 2018;10(5):e495-e498. https://doi. org/10.4317/jced.54497

21. More CB, Bhavsar K, Varma S, Tailor M. Oral mucocele: A clinical and histopathological study. J Oral Maxillofac Pathol. 2014;18(Suppl 1):S72-S77. https://doi.org/10.4103/0973029x.141370

22. Suryavanshi $R$, Abdullah $A$, Singh $N$, Astekar M. Oral mucocele in infant with an unusual presentation. BMJ Case Rep. 2020;13(6):e234669. https://doi.org/10.1136/ bcr-2020-234669

23. Abdel-Aziz M, Khalifa B, Nassar A, Kamel A, Naguib N, El-Tahan AR. Mucocele of the hard palate in children. Int $J$ Pediatr Otorhinolaryngol. 2016;85:46-49. https:// doi.org/10.1016/j.ijporl.2016.03.007

24. Ata N. Mucocele of the soft palate in a child. J Craniofac Surg. 2017;28(1):297298. https://doi.org/10.1097/ scs.0000000000003258

25. Zhang J, Wang C. The application of absolute ethanol in the treatment of mucocele of the glands of Blandin-Nuhn. J Craniofac Surg. 2016;27(7):e641-e642. https://doi. org/10.1097/scs.0000000000002993

26. Mandhan P, Napaki S, Ali M. Mucocele of the tongue. ANZ J Surg. 2017;87(12):E327-E328. https://doi. org/10.1111/ans.13180

27. Garcia Leon N, Marrugo Pardo GE. Mucocele of the glands of Blandin-Nuhn: a case report. Colomb Med (Cali). 2013;44(1):46-47. https://www.ncbi.nlm.nih.gov/pmc/articles/PMC4002008/

28. Brooks JK, Schwartz KG, Basile JR. Superficial mucocele of the ventral tongue: presentation of a rare case and literature review. J Oral Maxillofac Surg. 2016;74(6):1175-1179. https://doi.org/10.1016/j.joms.2015.11.025

29. Jose SC, Abraham KK, Khosla E. Blandin and Nuhn mucocele in a pediatric patient. $J$ Indian Soc Pedod Prev Dent. 2018;36(3):315318. https://doi.org/10.4103/jisppd.jisppd_10_18 